\title{
Responses to competition for nitrogen between subtropical native tree seedlings and exotic grasses are species-specific and mediated by soil $\mathrm{N}$ availability
}

\author{
Andrea Bueno ${ }^{1,5}$, Lucy Greenfield ${ }^{2,3}$, Karin Pritsch ${ }^{4}$, Susanne Schmidt ${ }^{2}$ and Judy Simon (D) 1 \\ ${ }^{1}$ Plant Interactions Ecophysiology Group, Department of Biology, University of Konstanz, Universitätsstrasse 10, 78457 Konstanz, Germany; ${ }^{2}$ Plant Nutrition and Ecophysiology \\ Group, School of Agriculture and Food Science, The University of Queensland, St Lucia Qld 4072, Australia; ${ }^{3}$ School of Earth and Environment, The University of Leeds, Leeds LS2 9JT, \\ UK; ${ }^{4}$ Institute of Biochemical Plant Pathology, HelmholtzZentrum München, Deutsches Forschungszentrum für Gesundheit und Umwelt GmbH, Ingolstaedter Landstrasse 1, 85764 \\ Oberschleißheim, Germany; ${ }^{5}$ Corresponding author (andrea.bueno@uni-konstanz.de)
}

Competitive interactions between native tree seedlings and exotic grasses frequently hinder forest restoration. We investigated the consequences of competition with exotic grasses on the growth and net nitrogen $(\mathrm{N})$ uptake capacity of native rainforest seedlings used for reforestation depending on soil $\mathrm{N}$ availability and $\mathrm{N}$ source. Tree seedlings and grasses were grown in the greenhouse in different competition regimes (one tree species vs one grass species) and controls (grass monocultures or single tree seedlings) at low and high soil $\mathrm{N}$. After 8 weeks, we quantified net $\mathrm{N}$ uptake capacity using ${ }^{15} \mathrm{~N}$-labelled organic (i.e., glutamine and arginine) and inorganic (i.e., ammonium and nitrate) $\mathrm{N}$ sources and biomass indices. Depending on soil $\mathrm{N}$ availability, we observed different speciesspecific responses to growth and $\mathrm{N}$ acquisition. Tree seedlings generally increased their net $\mathrm{N}$ uptake capacity in response to competition with grasses, although overall seedling growth was unaffected. In contrast, the responses to competition by the grasses were species-specific and varied with soil $\mathrm{N}$ availability. The different $\mathrm{N}$ acquisition strategies suggest the avoidance of competition for $\mathrm{N}$ between trees and grasses. Overall, the results highlight that quantifying underlying mechanisms of $\mathrm{N}$ acquisition complements the information on biomass allocation as a measure of responses to competition, particularly with varying environmental conditions.

Keywords: ammonium, interspecific competition, net nitrogen uptake capacity, nitrate, nitrogen acquisition, organic nitrogen, reforestation, subtropics.

\section{Introduction}

Plant-plant interactions shape the structure of plant communities (Callaway and Walker 1997, Brooker 2006, Tylianakis et al. 2008). Their magnitude and direction are influenced by factors including life stage, physiological requirements as well as environmental conditions (Callaway and Walker 1997). The interplay between these biotic and abiotic factors determines the outcome of species interactions which in turn affects the coexistence and spatial distribution of species (Brooker et al. 2008, Soliveres and Maestre 2014). A main interaction is the competition for resources such as soil nutrients. The ability of plants to acquire nutrients is determined by morphological and physiological traits, such as uptake rates of nutrients (Casper and Jackson 1997). By modifying nutrient uptake in response to environmental cues, such as nutrient availability, plants can be more competitive but the extent of such response varies (Hodge 2004).

Competitive interactions between native and exotic plant species are relevant in the context of global environmental change, because there is evidence that the predicted changes in the abiotic environment will likely influence competition in favour of exotic species (Bradley et al. 2010, Verlinden et al. 2014). The superior competitive ability of exotic plant species is frequently a key factor promoting invasions, with exotic species able to better exploit limited resources, to the detriment of native species 
(D'Antonio and Vitousek 1992, Gioria and Osborne 2014). Changing nutrient status, such as increased nitrogen (N) availability with atmospheric deposition, can alter plant growth and biomass allocation in a species-specific manner, and consequently results in shifts in the outcome of interspecific competition (Rennenberg et al. 2009). Here, we investigate the competition between exotic and native plants comparing the response strategies of different species, and how resource availability modulates these interactions. A focus on $\mathrm{N}$ physiology is warranted because $\mathrm{N}$ is quantitatively the most important of soilacquired nutrients (Marschner 1995), limits plant growth in most ecosystems (Agren et al. 2012), drives competition (Eller and Oliveira 2017), and N availability and uptake can vary considerably in response to environmental change (BassiriRad 2000, Kuster et al. 2016). Since most studies focus on biomass production as indicator of the magnitude and direction of competitive interactions, even though other factors besides competition may influence biomass, (Trinder et al. 2013), we also examined net $\mathrm{N}$ uptake as a process that underlies the interaction between native and exotic species, because exotic species might alter soil $\mathrm{N}$ availability, show strong preferences to certain $\mathrm{N}$ forms and/or interfere with the $\mathrm{N}$ acquisition of native species, therefore affecting their performance (Fraterrigo et al. 2011, Huangfu et al. 2016, Eller and Oliveira 2017).

While earlier studies have focused mainly on the acquisition of inorganic $\mathrm{N}$, organic $\mathrm{N}$ uptake has received increasing attention due to its potential to drive niche differentiation and species coexistence, and therefore ecosystem stability (Schmidt and Stewart 1999, McKane et al. 2002, Kielland et al. 2006, Näsholm et al. 2009, Ashton et al. 2010). A plant's ability to use a wider array of $\mathrm{N}$ sources can result in competition avoidance (e.g., Miller et al. 2007, Simon et al. 2010, Simon et al. 2014, Li et al. 2015). Studies that have quantified the uptake of organic and inorganic $\mathrm{N}$ forms found species-specific preferences for different $\mathrm{N}$ forms (e.g., Persson et al. 2003, Weigelt et al. 2005, Simon et al. 2010, Li et al. 2015). For example, European beech (Fagus sylvatica) shows a preference for organic rather than inorganic $\mathrm{N}$, whereas the opposite is true for sycamore maple (Acer pseudoplatanus) (Li et al. 2015). In a study on excised roots of native and exotic grasses of Australian savannas, a general preference for ammonium was found, but preferences for nitrate and the amino acid glycine were species-specific (Rossiter-Rachor et al. 2009). Furthermore, the uptake capacity of different $\mathrm{N}$ sources is influenced by interspecific competition (e.g., Miller et al. 2007, Simon et al. 2010, Simon et al. 2014, Li et al. 2015). For example, when grown in competition with sycamore maple, the capacity for organic $\mathrm{N}$ uptake of European beech seedlings was reduced (Simon et al. 2014). However, the responses of competition with regard to $\mathrm{N}$ acquisition are also influenced by environmental factors (Simon et al. 2014, $\mathrm{Li}$ et al. 2015). Overall, most studies that have examined the acquisition of different $\mathrm{N}$ forms in context of competition have focused either on herbaceous or woody species in temperate ecosystems, rather than the interactions between trees and grasses. These, however, are important in the context of conservation and ecosystem restoration, because the successful establishment of tree seedlings (commonly planted in order to restore a plant community) often depends on the outcome of their interaction with grasses (Erskine et al. 2005, Doust et al. 2008, Elgar et al. 2014), where $\mathrm{N}$ is likely to play a determinant role (Coll et al. 2004, Barbosa et al. 2014).

Tree-grass interactions have been broadly studied in savanna ecosystems measuring the influence of abiotic factors (e.g., light, water and nutrient availability) that mediate the interaction (e.g., Ludwig et al. 2001, van der Waal et al. 2009, Moustakas et al. 2013) and in studies investigating the long-term coexistence of these contrasting life forms (e.g., Jeltsch et al. 2000, Sankaran et al. 2004). With regard to forest regeneration, tree-grass interactions have been studied in the context of secondary succession, tree regeneration in forest gaps after disturbances, or meadows (e.g., Coll et al. 2004, Bloor et al. 2008a, Elgar et al. 2014), where tree seedlings interact with the already established plant community commonly composed of early successional life forms, including grasses. However, research on the effect of herbaceous vegetation on tree seedlings mainly focusses on seedling survival and growth (e.g., Davis et al. 1998, Bloor et al. 2008b, Meli and Dirzo 2013), physiological aspects such as water relations (e.g., Quinteros et al. 2017) or photosynthesis (e.g., Davis et al. 1999, Loik and Holl 2001), while competition for nutrients, specifically $\mathrm{N}$, has received little attention despite the potential of belowground competition with grasses to influence tree growth and establishment (e.g., Cramer et al. 2010) and the influence of soil $\mathrm{N}$ availability on the competition outcome (e.g., Cramer et al. 2012).

Here, we studied the interactions between native tree seedlings and exotic grasses because ecological forest restoration efforts are frequently hindered by competition from exotic grasses (Kanowski et al. 2003, Erskine et al. 2005). In reforestation programs, grasses successfully establish even after the planting of seedlings without regular weeding. To mimic these conditions, we used nursery-grown tree seedlings and grasses grown from seed in our study. We selected tree species that are relevant in the context of restoration of riparian zones in subtropical Australia (Catteral and Harrison 2006, Gageler et al. 2014), including an $\mathrm{N}_{2}$ fixer. Tree species with the capacity to fix atmospheric $\mathrm{N}_{2}$ via symbiotic rhizobacteria in root nodules are commonly used in restoration programs with the intent to improve the overall $\mathrm{N}$ supply at a site (Erskine et al. 2005). Their $\mathrm{N}_{2}$ fixing ability would make them largely independent from external soil $\mathrm{N}$ supply (Messina and Barton 1985) and potentially alleviate competition for $\mathrm{N}$ (Epron et al. 2006). We conducted a greenhouse experiment to advance the understanding of whether competition for $\mathrm{N}$ plays a role in the interaction between seedlings of two native tree species and two exotic grass species, and the potential effects of soil $\mathrm{N}$ availability. 
Our objectives were to (i) determine the effect of interspecific competition on inorganic and organic $\mathrm{N}$ acquisition and biomass indices as response strategies of tree seedlings and grasses, and (ii) evaluate the impact of low vs high soil $\mathrm{N}$ availability on the competition outcome in terms of $\mathrm{N}$ acquisition. We hypothesized that tree seedlings and grasses potentially avoid competition by using different $\mathrm{N}$ forms (i.e., fast-growing grasses using inorganic forms and relatively slow-growing trees using organic forms), that growth and net $\mathrm{N}$ uptake capacity of tree seedlings is negatively affected in the presence of competing exotic grasses, and that this negative effect is lessened at high soil $\mathrm{N}$ availability.

\section{Materials and methods}

\section{Study species and plant material}

We selected two native tree species used in riparian reforestation in the Maleny region $\left(26.7^{\circ} \mathrm{S}, 152.8^{\circ} \mathrm{E}\right.$, Queensland, Australia), angiosperm Acacia melanoxylon R.Br (Fabaceae) and gymnosperm Podocarpus elatus R.Br. ex Endl. (Podocarpaceae). Acacia melanoxylon is an early successional, $\mathrm{N}_{2}$ fixing species native to south-east Australia (Smith et al. 2008, Birnbaum et al. 2012) that occurs in rainforests and wet sclerophyll forests (Doran and Turnbull 1997). Podocarpus elatus is a latesuccessional endemic species that grows in subtropical rainforests (Smith et al. 2008). Seedlings of $A$. melanoxylon (5 months old, $\sim 40 \mathrm{~cm}$ tall) and $P$. elatus (10 months old, $\sim 30 \mathrm{~cm}$ tall) were obtained from a local nursery (Brush Turkey Enterprises, Maleny, Australia). We selected tree species with contrasting successional status to explore potential differences in their $\mathrm{N}$ acquisition strategies related to growth rate (Li et al. 2015), and species adaptation to $\mathrm{N}$ forms available in soils of different successional status (e.g., higher nitrate availability in early successional sites compared to late sites) (Kronzucker et al. 1997, Britto and Kronzucker 2013). The exotic grasses Pennisetum clandestinum Hochst. ex Chiov. (Poaceae) and Cynodon dactylon (L.) Pers. (Poaceae) are perennial, originate from Africa and have been introduced to tropical areas around the world (Judd 1979). Spreading via rhizomes, stolons and seeds, these grasses naturally occur in grasslands and are common in pastures and lawns in their introduced range (Judd 1979). In subtropical Australia, these two grass species are reported as a threat to restoration efforts, and their negative effects on the growth of native tree seedlings have been observed in the field (M. Amos, personal communication). Grass seeds were purchased from Royston Petrie Seeds (Mudgee, Australia). From here on, species will be referred to by their genus, i.e., Acacia, Podocarpus, Pennisetum and Cynodon.

\section{Experimental setup}

Tree seedlings were planted and grasses were sown from seed into 1 I pots (125 mm diameter, Anova Solutions, Brisbane, Australia) with a 1:1 mixture of grade $A$ pit sand (grain size:
$0.5 \mathrm{~mm}$ ) and $\mathrm{G} 2$ vermiculite (grain size: $1-2 \mathrm{~mm}$ ) in interspecific competition or under control conditions at low and high soil $\mathrm{N}$ availability. Competition treatments consisted of one tree individual surrounded by 10-12 individual grasses that were uniformly distributed $\sim 4 \mathrm{~cm}$ from the seedling stem. The four species combinations were Acacia vs Pennisetum, Acacia vs Cynodon, Podocarpus vs Pennisetum and Podocarpus vs Cynodon. Control treatments consisted either of a single tree seedling or 12 individuals of one grass species (i.e., monoculture). Tree seedlings were not large enough to result in shading for the grasses (A. Bueno, pers. obs.). Because competition for $\mathrm{N}$ is highest under conditions of $\mathrm{N}$ limitation (Wilson and Tilman 1991, Casper and Jackson 1997), all competition regimes received the low soil $\mathrm{N}$ treatment. To ensure sufficient replication, the high soil $\mathrm{N}$ treatment was only applied for tree species vs Pennisetum because Cynodon had poor germination rates. Therefore, it was excluded from the high soil $\mathrm{N}$ treatment to ensure sufficient replicates in the low soil $\mathrm{N}$ treatment. For each combination of competition regime and soil $\mathrm{N}$ availability treatment, ten replicates were established. To control for the variation in initial size of the seedlings, we recorded the initial aboveground size of all tree seedlings (i.e., stem length measured from root crown, number of leaves and length of largest leaf) before planting. Pots were watered with tap water every second day to field capacity until the grasses germinated which occurred within 2 weeks of planting. Soil $\mathrm{N}$ availability treatments therefore commenced 2 weeks after planting. Subsequently, once a week $100 \mathrm{ml}$ of nutrient solution was applied, with low or high $\mathrm{N}$ concentrations, for low $\mathrm{N}$ : $1 \mu \mathrm{M} \mathrm{NH}{ }_{4} \mathrm{Cl}, 100 \mu \mathrm{M} \mathrm{KNO}_{3}, 25 \mu \mathrm{M}$ glutamine and $25 \mu \mathrm{M}$ arginine; high $\mathrm{N}: 40 \mu \mathrm{M} \mathrm{NH}{ }_{4} \mathrm{Cl}, 400 \mu \mathrm{M}$ $\mathrm{KNO}_{3}, 100 \mu \mathrm{M}$ glutamine and $100 \mu \mathrm{M}$ arginine, based on soil $\mathrm{N}$ availability in previous low vs high soil $\mathrm{N}$ studies (Simon et al. 2013) based on a low and high $N$ forest site (Dannenmann et al. 2009, Stoelken et al. 2010, respectively), and on the occurrence of glutamine and arginine in subtropical Queensland soils (Holst et al. 2012). Other nutrients applied at the same rate in both $\mathrm{N}$ treatments were: $10 \mu \mathrm{M} \mathrm{AlCl}_{3}, 90 \mu \mathrm{M} \mathrm{CaCl}_{2}, 7 \mu \mathrm{M}$ $\mathrm{FeSO}_{4}, 6 \mu \mathrm{M} \mathrm{K}_{2} \mathrm{HPO}_{4}, 50 \mu \mathrm{M} \mathrm{KCl}, 24 \mu \mathrm{M} \mathrm{MnCl}, 20 \mu \mathrm{M} \mathrm{NaCl}$ and $70 \mu \mathrm{M} \mathrm{MgCl}_{2}$. The experiment was conducted in a naturally lit greenhouse at The University of Queensland, St. Lucia Campus (Brisbane, Australia), between April and June 2015. Average temperature recorded in the greenhouse was $24.7 \pm$ $3.7^{\circ} \mathrm{C}$ during the day and $20.3 \pm 1.8^{\circ} \mathrm{C}$ at night, reaching a minimum of $13.5^{\circ} \mathrm{C}$ and a maximum of $35.3^{\circ} \mathrm{C}$.

\section{${ }^{15} \mathrm{~N}$ uptake experiments and harvest}

Eight weeks after commencing the $\mathrm{N}$ treatments (and 10 weeks after planting), the net inorganic (i.e., ammonium, nitrate) and organic (i.e., glutamine, arginine) N uptake capacity of fine roots of tree seedlings and grasses was quantified following the ${ }^{15} \mathrm{~N}$ enrichment technique described by Gessler et al. (1998) as modified by Simon et al. (2010) using fine roots still attached to 
the individuals. For this, we carefully removed the plants from the pots and washed the roots to remove adherent soil particles. Fine roots were then incubated for a $2 \mathrm{~h}$ period in $4 \mathrm{ml}$ artificial nutrient solution containing all four $\mathrm{N}$ sources (as described above), but with one of the sources labelled as either ${ }^{15} \mathrm{~N}$-ammonium, ${ }^{15} \mathrm{~N}$-nitrate, ${ }^{13} \mathrm{C} /{ }^{15} \mathrm{~N}$-glutamine or ${ }^{13} \mathrm{C} /{ }^{15} \mathrm{~N}$ arginine. Amino acids were ${ }^{13} \mathrm{C} /{ }^{15} \mathrm{~N}$ double-labelled to determine whether they were taken up as intact molecules or degraded over the time of incubation (Simon et al. 2011). Additionally, we used artificial soil solution without ${ }^{15} \mathrm{~N}$-label to account for the natural abundance of ${ }^{15} \mathrm{~N}$ in the roots of each species for all treatment levels. Plants were incubated in either low or high $\mathrm{N}$ artificial soil solution matching the soil $\mathrm{N}$ availability treatment to which they had been subjected. Root incubation occurred between 10 a.m. and 2 p.m. to avoid diurnal variation in $\mathrm{N}$ uptake (Gessler et al. 2002), i.e., the incubation period of $2 \mathrm{~h}$ for any given individual sample started between $10 \mathrm{a} . \mathrm{m}$. and 12 p.m. and ended between 12 and 2 p.m. For the duration of the ${ }^{15} \mathrm{~N}$ incubation experiments, the remaining seedling's roots were carefully wrapped in wet tissue to prevent drying out. A total of six replicate root samples were set up for each of the four $\mathrm{N}$ sources (plus controls for natural abundance) per species, competition regime and soil $\mathrm{N}$ availability level. Depending on the size of the root system for an individual plant, one to four $\mathrm{N}$ sources plus control were tested per individual. After the incubation period, fine roots were carefully cut, washed twice in 0.5 $\mathrm{M} \mathrm{CaCl}_{2}$ solution to remove the incubation solution from the root surface, and dried with tissue. Following the ${ }^{15} \mathrm{~N}$ uptake experiments, we separated the plants into above- and belowground organs, i.e., the tree seedlings into leaves, stem and roots, and the grasses into shoots and roots, since no stem had developed. We determined the fresh weight (fw) of all plant tissues and the incubated fine roots, oven dried the samples at $65^{\circ} \mathrm{C}$ for $72 \mathrm{~h}$ and determined their dry weight ( $\mathrm{dw}$ ) to obtain biomass indices.

\section{Quantification of total $\mathrm{N}$ and $\mathrm{C},{ }^{15} \mathrm{~N}$ and ${ }^{13} \mathrm{C}$ in fine roots}

To quantify ${ }^{15} \mathrm{~N}$ and ${ }^{13} \mathrm{C}$ enrichment the dried fine roots were ground using a ball mill (TissueLyser, Retsch, Haan, Germany). Aliquots of $1.2-2.5 \mathrm{mg}$ of the resulting homogeneous fine powder were weighed into $4 \times 6 \mathrm{~mm}$ tin capsules (IVA Analysentechnik, Meerbusch, Germany), and analysed with an isotope ratio mass spectrometer (Delta V Advantage, Thermo Electron, Dreieich, Germany) coupled to an elemental analyser (Euro EA, Eurovector, Milan, Italy). $\Delta$ values were calculated using a laboratory standard (acetanilide) that was part of every sequence in intervals, and also used in different weights to determine isotope linearity of the system. The laboratory standard was calibrated against different international standards from IAEA (Vienna): for ${ }^{15} \mathrm{~N}$ USGS 40 $\left(\delta^{15} N_{\text {Air }}=-4.5 \%\right)$, IAEA $600\left(\delta^{15} N_{\text {Air }}=+1.0 \%\right)$, IAEA N2 $\left(\delta^{15} N_{\text {Air }}=+20.3 \%\right)$, USGS $41\left(\delta^{15} N_{\text {Air }}=+47.6 \%\right)$, USGS 26 $\left(\delta^{15} N_{\text {Air }}=+53.7 \%\right.$ ) , and USGS $32\left(\delta^{15} N_{\text {Air }}=+180 \%\right.$ ) , and for
${ }^{13} \mathrm{C}$ IAEA $600\left(\delta^{13} C_{V-P D B}=-27.77 \%\right)$, IAEA $3\left(\delta^{13} C_{V-P D B}=\right.$ $-24.72 \% 0)$, and IAEA CH6 $\left(\delta^{13} C_{V-P D B}=-10.45\right) .{ }^{15} \mathrm{~N}$ results of highly enriched samples were finally corrected with different enriched ${ }^{15} \mathrm{~N}$ standards (from 0.437 to 0.734 at \%) from Fischer Analysen Instrumente (Leipzig, Germany). $\Delta$ values are defined as $\delta$ $[\%$ o $]=\left(R_{\mathrm{SA}} / R_{\mathrm{Std}}-1\right) * 1000$, where $R$ is the ratio of heavy isotope against light isotope (i.e., ${ }^{13} \mathrm{C} /{ }^{12} \mathrm{C}$ and ${ }^{15} \mathrm{~N} /{ }^{14} \mathrm{~N}$ ), SA is sample and Std the international reference for the respective element (V-PDB for ${ }^{13} \mathrm{C}$ and air- $\mathrm{N}_{2}$ for ${ }^{15} \mathrm{~N}$ ). For each of the four $\mathrm{N}$ sources, we then calculated net $\mathrm{N}$ uptake capacity ( $\mathrm{nmol} \mathrm{N} \mathrm{g}{ }^{-1} \mathrm{fw} \mathrm{h}^{-1}$ ) based on the incorporation of ${ }^{15} \mathrm{~N}$ into root fresh weight according to Gessler et al. (1998): net $\mathrm{N}$ uptake capacity $=\left(\left({ }^{15} \mathrm{~N}_{\Gamma}{ }^{15} \mathrm{~N}_{\mathrm{c}}\right) * \mathrm{~N}_{\text {tot }} * \mathrm{dw} * 10^{5}\right)$ $(\mathrm{MW} * \mathrm{fw} * t){ }^{-1}$, where ${ }^{15} \mathrm{~N}_{\mathrm{l}}$ and ${ }^{15} \mathrm{~N}_{\mathrm{c}}$ are the atom\% of ${ }^{15} \mathrm{~N}$ in labelled $\left(\mathrm{N}_{\mathrm{l}}\right)$ and control plants ( $\mathrm{N}_{\mathrm{C}}$, natural abundance), respectively, $\mathrm{N}_{\text {tot }}$ is the total $\mathrm{N}$ percentage, $\mathrm{MW}$ is the molecular weight $\left({ }^{15} \mathrm{Ng} \mathrm{mol}^{-1}\right)$, and $t$ represents the incubation time (120 min). Based on ${ }^{13} \mathrm{C}$ incorporation, net uptake capacity of glutamine and arginine was $\sim 60 \%$ and $\sim 95 \%$, respectively, compared to that based on ${ }^{15} \mathrm{~N}$ incorporation, which indicates (1) the degradation of amino acids in the solution or on the root surface, and/or (2) the respiration of amino acid-derived $\mathrm{C}$ inside the roots (Simon et al. 2011).

\section{Statistical analysis}

For all species, we tested for differences between treatments for total biomass and root:shoot ratio as well as net uptake capacity of the four $\mathrm{N}$ sources by performing Permutational ANOVAs (PERMANOVA) based on a Euclidean resemblance matrix between samples (Anderson et al. 2008). PERMANOVA was chosen as a non-parametric univariate test equivalent to ANOVA (Anderson et al. 2008). We performed two-way PERMANOVAs using 'competition regime' and 'soil $\mathrm{N}$ availability' as orthogonal factors. For the tree species, the 'competition regime' factor had three levels: control, competition with Pennisetum, and competition with Cynodon. Moreover, for the tree seedlings biomass and root:shoot ratio analyses, initial size measurements of the tree seedlings were included as a covariate. For the grass species, the three levels were: control, competition with Acacia, and competition with Podocarpus. The 'soil $\mathrm{N}$ availability' factor included two levels: high $\mathrm{N}$ and low $\mathrm{N}$ for Acacia, Podocarpus and Pennisetum. For the grass Cynodon, we performed one-way PERMANOVAs, considering the factor 'competition regime' with three levels: control, competition with Acacia, and competition with Podocarpus, all at low soil $\mathrm{N}$ availability as described above. When a significant interaction between factors was found, post hoc PERMANOVA pairwise comparisons were performed. To test for differences in net $\mathrm{N}$ uptake capacity between species, one-way PERMANOVAs were performed on the control data (i.e., no competition), using species as factor, for each $\mathrm{N}$ form. To test for preferences in net uptake capacity of the four $\mathrm{N}$ sources for a given species, one-way PERMANOVAs were performed, using $\mathrm{N}$ source as factor, for each combination of competition regime and soil $\mathrm{N}$ availability treatment. All analyses 
were performed using PRIMER 6.0 with the PERMANOVA+ addon (PRIMER-E Ltd, Plymouth, UK), and figures were prepared in SigmaPlot 13.0 (Systat Software Inc., San Jose, USA).

\section{Results}

\section{Effects of competition regime and soil $N$ availability on biomass and root:shoot ratio}

Native tree seedlings and exotic grasses responded differently in biomass production depending on competition regime and soil $\mathrm{N}$ availability (Figure 1). For the tree species, neither Acacia nor Podocarpus differed significantly in total biomass between single and competing seedlings regardless of soil $\mathrm{N}$ availability (Figure 1; see Supplementary Table S1 available as Supplementary Data at Tree Physiology Online). Positive correlations were found for Acacia between total biomass and the initial leaf number, for Podocarpus between total biomass and both initial leaf number and initial stem length (both p-perm < 0.001, data not shown). This indicates that total biomass at the end of the experiment was a function of initial tree seedling size. For the grass Pennisetum, total biomass was significantly reduced in competition with Acacia or Podocarpus compared to the control at high soil $\mathrm{N}$ availability, and it was also significantly reduced at low compared to high soil $\mathrm{N}$ availability irrespective of the competition regime (Figure 1; see Table S2 available as Supplementary Data at Tree Physiology Online). For the grass Cynodon, competition with Acacia significantly reduced total biomass compared to competition with Podocarpus or control (at low soil $\mathrm{N}$ availability) (Figure 1; see Table S2 available as Supplementary Data at Tree Physiology Online).

Root:shoot ratio was not affected by soil $\mathrm{N}$ availability or competition regime for both tree species as well as competition regimes for the grass Cynodon at low soil $\mathrm{N}$ availability (Figure 1). For the grass Pennisetum, root:shoot ratio was significantly lower in competition with Podocarpus compared to competition with Acacia or controls irrespective of soil $\mathrm{N}$ availability (Figure 1).

\section{Effects of competition regime and soil $N$ availability on inorganic and organic net $N$ uptake capacity}

Inorganic and organic net $\mathrm{N}$ uptake capacity of all species increased significantly with high compared to low soil $\mathrm{N}$
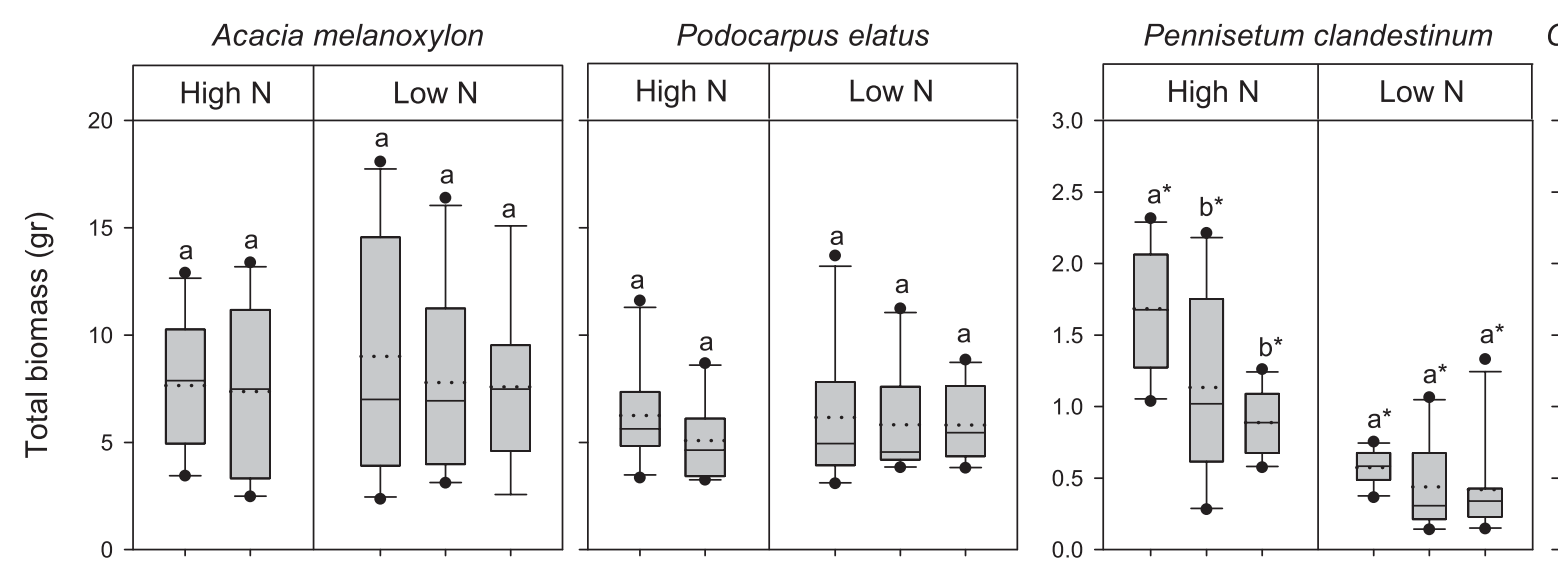

Cynodon dactylon
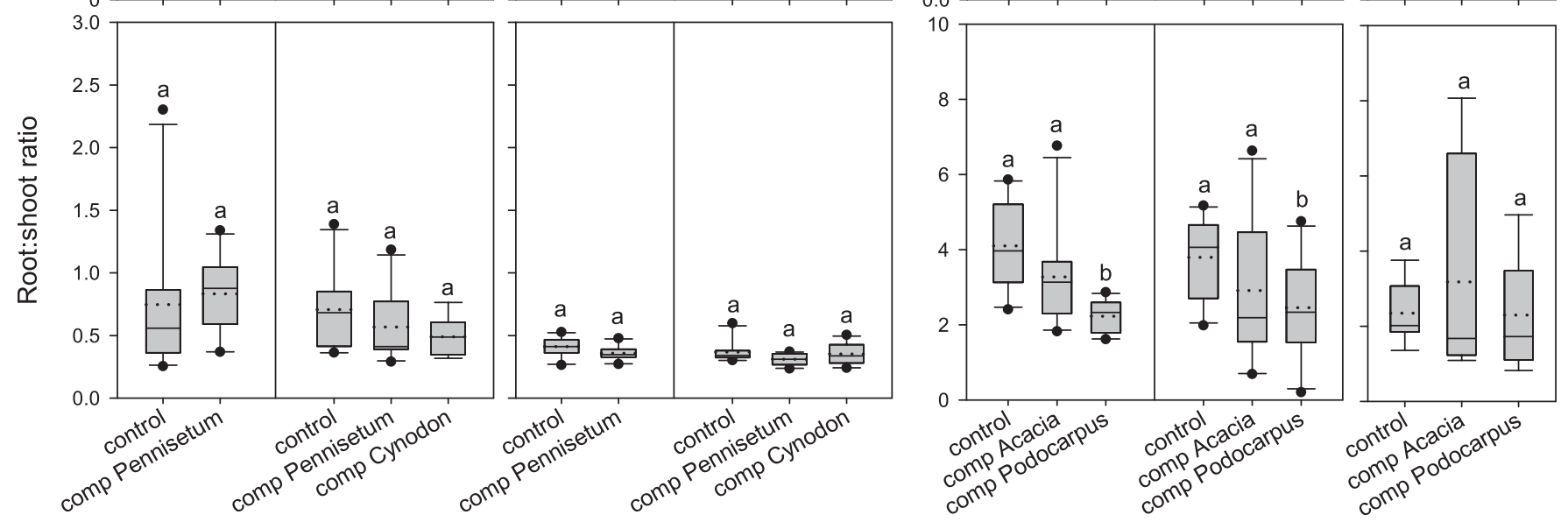

Figure 1. Total biomass and root:shoot ratio of Acacia melanoxylon, Podocarpus elatus, Pennisetum clandestinum and Cynodon dactylon, at low and high soil $\mathrm{N}$ availability under different competition regimes. For $\mathrm{C}$. dactylon, only low soil $\mathrm{N}$ data is available. comp Pennisetum $=$ competition with $P$. clandestinum; comp Cynodon = competition with $C$. dactylon; comp Acacia = competition with $A$. melanoxylon; comp Podocarpus = competition with $P$. elatus. Box plots show mean (dotted line) and median (straight line). Different letters indicate significant differences between competition regimes within a specific soil $\mathrm{N}$ availability treatment, and asterisks indicate significant differences between soil $\mathrm{N}$ availability treatments, detected using permutational analysis of variance $(P<0.05)$. 
availability, whereas the responses to competition regime differed depending on the species (Figures 2 and 3; see Table S3 available as Supplementary Data at Tree Physiology Online). Inorganic and organic net $\mathrm{N}$ uptake capacity of Acacia seedlings increased with higher soil $\mathrm{N}$ availability regardless of competition regime. At high soil $\mathrm{N}$ availability, net ammonium uptake capacity of Acacia seedlings competing with the grass Pennisetum increased significantly compared to seedlings growing without competition (Figure 2; see Supplementary Table S4 available as Supplementary Data at Tree Physiology Online), but no change for nitrate (Figure 2), glutamine-N or arginine-N (Figure 3) was found at either low or high soil $\mathrm{N}$ availability. Similarly, inorganic $\mathrm{N}$ (Figure 2) and arginine-N (Figure 3) net uptake capacity of Podocarpus increased with high compared to low soil $\mathrm{N}$ availability irrespective of competition regime. However, net glutamine- $\mathrm{N}$ uptake capacity increased with higher soil $\mathrm{N}$ availability only for Podocarpus seedlings grown in competition with Pennisetum (Figure 3; see Table S4 available as Supplementary Data at Tree Physiology Online). At high soil $\mathrm{N}$ availability, competition with Pennisetum increased net glutamine-N uptake capacity of
Podocarpus seedlings compared to seedlings growing alone (Figure 3); however, net ammonium, nitrate (Figure 2), and arginine-N (Figure 3) uptake capacity were not affected. For the grass Pennisetum, net ammonium and organic N, but not nitrate uptake capacity were significantly higher at high compared to low soil $\mathrm{N}$ availability (Figures 2 and 3). For Pennisetum, competition regime had no significant effect on organic (Figure 3) and inorganic (Figure 2) net $\mathrm{N}$ uptake capacity at either low or high soil $\mathrm{N}$ availability. At low soil $\mathrm{N}$ availability, nitrate, but not ammonium or organic net $\mathrm{N}$ uptake capacity of the grass Cynodon was significantly higher when grown in competition with Podocarpus compared to that with Acacia, or control (Figures 2 and 3; see Table S4 available as Supplementary Data at Tree Physiology Online).

\section{Differences between species with regard to inorganic and organic N acquisition}

In the absence of interspecific competition (i.e., single grown tree seedlings or grasses growing in monocultures), species differed in their inorganic and organic $\mathrm{N}$ acquisition strategies

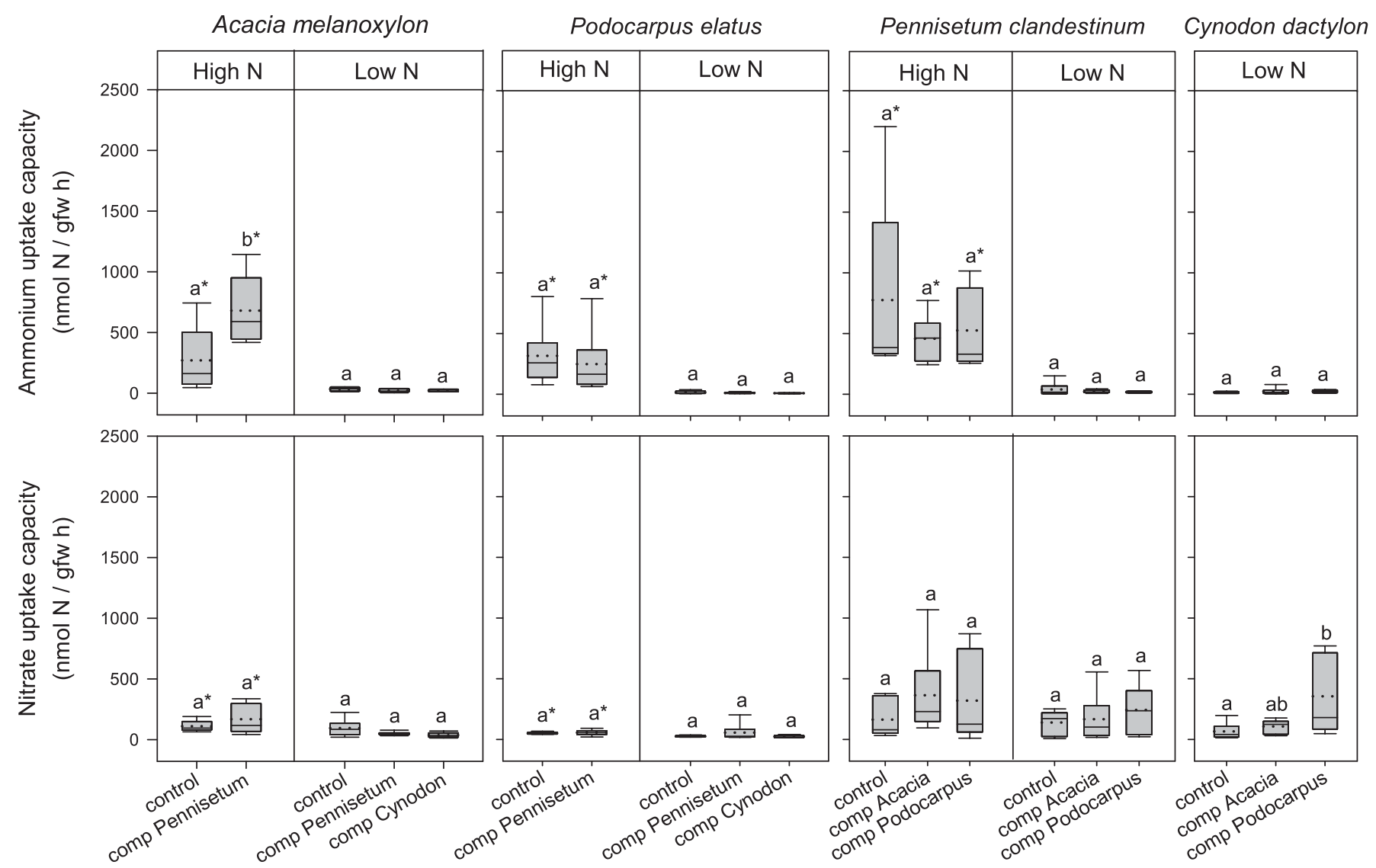

Figure 2. Ammonium $\left(\mathrm{NH}_{4}^{+}\right)$and nitrate $\left(\mathrm{NO}_{3}{ }^{-}\right)$net uptake capacity $\left(\mathrm{nmol} \mathrm{N} \mathrm{g}{ }^{-1} \mathrm{fw} \mathrm{h}{ }^{-1}\right)$ by fine roots of Acacia melanoxylon, Podocarpus elatus, Pennisetum clandestinum and Cynodon dactylon at low and high soil $\mathrm{N}$ availability under different competition regimes. For $\mathrm{C}$. dactylon, only low soil $\mathrm{N}$ data is available. comp Pennisetum = competition with $P$. clandestinum; comp Cynodon = competition with $C$. dactylon; comp Acacia $=$ competition with A. melanoxylon; comp Podocarpus $=$ competition with $P$. elatus. Box plots show mean (dotted line) and median (straight line). Different letters indicate significant differences between competition regimes within a specific soil $\mathrm{N}$ availability treatment, and asterisks indicate significant differences between soil $\mathrm{N}$ availability treatments detected using permutational analysis of variance $(P<0.05)$ 


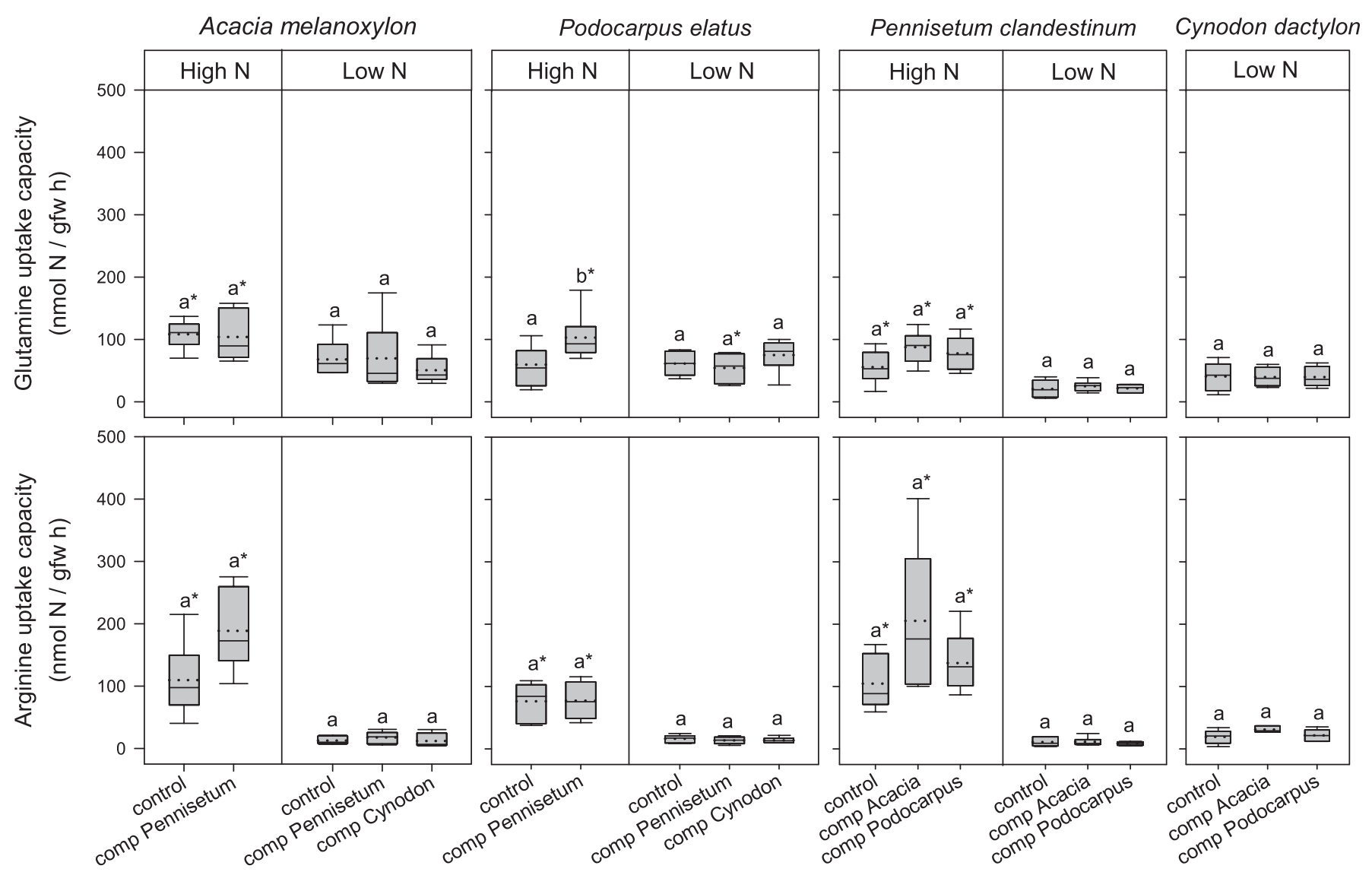

Figure 3. Glutamine-N (Gln-N) and arginine-N (Arg-N) net uptake capacity (nmol N g ${ }^{-1} \mathrm{fw} \mathrm{h}^{-1}$ ) by fine roots of Acacia melanoxylon, Podocarpus elatus, Pennisetum clandestinum and Cynodon dactylon at low and high soil $\mathrm{N}$ availability under different competition regimes. For $\mathrm{C}$. dactylon, only low soil $\mathrm{N}$ data is available. comp Pennisetum = competition with $P$. clandestinum; comp Cynodon = competition with $C$. dactylon; comp Acacia = competition with A. melanoxylon; comp Podocarpus = competition with $P$. elatus. Box plots show mean (dotted line) and median (straight line). Different letters indicate significant differences between competition regimes within a specific soil $\mathrm{N}$ availability treatment, and asterisks indicate significant differences between soil $\mathrm{N}$ availability treatments detected using permutational analysis of variance $(P<0.05)$.

depending on the $\mathrm{N}$ source: seedlings of Podocarpus took up significantly less nitrate than seedlings of Acacia and the grass Pennisetum, irrespective of soil $\mathrm{N}$ availability (Table 1). However, glutamine-N acquisition of Pennisetum was significantly lower than that of Podocarpus, which in turn was lower than that of Acacia seedlings at both low and high soil $\mathrm{N}$ availability (Table 1). No differences were found between any of the species with regard to ammonium and arginine- $\mathrm{N}$ acquisition (Table 1).

General preference patterns of the different $\mathrm{N}$ forms were found for each species within each competition regime depending on soil $\mathrm{N}$ availability: At low soil $\mathrm{N}$ availability, both tree species preferred nitrate and glutamine-N over ammonium and arginine-N (see Table S5 available as Supplementary Data at Tree Physiology Online). However, at high soil N availability, this pattern was reversed with ammonium and arginine- $\mathrm{N}$ being favoured over nitrate and glutamine- $\mathrm{N}$ for both tree species (Table 2; see Table S5 available as Supplementary Data at Tree Physiology Online). For the grasses, inorganic $N$ sources, particularly nitrate, were preferred over organic $\mathrm{N}$ sources (regardless of soil $\mathrm{N}$ availability for Pennisetum) (Table 2; see Table S6 available as Supplementary Data at Tree Physiology Online).

\section{Discussion}

Our study provides novel insight into the species-specific growth and $\mathrm{N}$ acquisition patterns in native tree seedlings and exotic grasses competing for N. Depending on soil N availability, native tree seedlings responded to competition with increases in $\mathrm{N}$ acquisition only, whereas the responses of the grasses in terms of biomass and $\mathrm{N}$ acquisition varied with species and soil $\mathrm{N}$ availability. These results highlight that quantifying underlying mechanisms complements biomass indices to advance the understanding of interspecific competition (Trinder et al. 2013). Furthermore, the lack of response with regard to biomass in the tree seedlings compared to the grasses suggests that $\mathrm{N}$ storage capacity plays a role in the growth response as well. 
Table 1. PERMANOVA results of the differences in ammonium $\left(\mathrm{NH}_{4}{ }^{+}\right)$, nitrate $\left(\mathrm{NO}_{3}{ }^{-}\right)$, glutamine- $\mathrm{N}(\mathrm{Gln}-\mathrm{N})$ and arginine-N (Arg-N) net uptake capacity of fine roots between Acacia melanoxylon, Podocarpus elatus, Pennisetum clandestinum and Cynodon dactylon. Significant values are indicated in bold.

\begin{tabular}{|c|c|c|c|c|c|c|c|c|}
\hline \multirow[b]{2}{*}{ Main test } & \multicolumn{2}{|l|}{$\mathrm{NH}_{4}^{+}$} & \multicolumn{2}{|l|}{$\mathrm{NO}_{3}^{-}$} & \multicolumn{2}{|l|}{ Gln-N } & \multicolumn{2}{|l|}{ Arg-N } \\
\hline & Pseudo-F & $\mathrm{P}($ perm $)$ & Pseudo-F & $\mathrm{P}($ perm $)$ & Pseudo-F & $\mathrm{P}($ perm $)$ & Pseudo-F & $P($ perm $)$ \\
\hline Species & 1.630 & 0.170 & 4.248 & 0.013 & 7.469 & $<0.001$ & 0.573 & 0.648 \\
\hline Soil $\mathrm{N}$ availability & 16.749 & $<0.001$ & 0.674 & 0.419 & 8.259 & 0.006 & 65.941 & $<0.001$ \\
\hline Species $\times$ Soil $N$ availability & 2.184 & 0.098 & 0.011 & 0.991 & 2.545 & 0.092 & 1.307 & 0.295 \\
\hline Pairwise comparisons & $\mathrm{t}$ & $P($ perm $)$ & $\mathrm{t}$ & $P($ perm $)$ & $\mathrm{t}$ & $P($ perm $)$ & $\mathrm{t}$ & $P($ perm $)$ \\
\hline Acacia vs Podocarpus & \multirow{6}{*}{\multicolumn{2}{|c|}{ Not applicable }} & 3.843 & $<0.001$ & 2.493 & 0.022 & \multirow{6}{*}{\multicolumn{2}{|c|}{ Not applicable }} \\
\hline Acacia vs Pennisetum & & & 1.180 & 0.251 & 4.766 & $<0.001$ & & \\
\hline Acacia vs Cynodon & & & 0.803 & 0.441 & 1.771 & 0.096 & & \\
\hline Podocarpus vs Pennisetum & & & 3.0987 & 0.005 & 2.207 & 0.041 & & \\
\hline Podocarpus vs Cynodon & & & 1.760 & 0.066 & 1.401 & 0.179 & & \\
\hline Pennisetum vs Cynodon & & & 1.125 & 0.271 & 1.509 & 0.157 & & \\
\hline
\end{tabular}

Table 2. Differences between ammonium $\left(\mathrm{NH}_{4}{ }^{+}\right)$, nitrate $\left(\mathrm{NO}_{3}{ }^{-}\right)$, glutamine-N $(\mathrm{Gln}-\mathrm{N})$ and arginine- $\mathrm{N}$ (Arg-N) net uptake capacity of fine roots of Acacia melanoxylon, Podocarpus elatus, Pennisetum clandestinum and Cynodon dactylon, at low and high soil $\mathrm{N}$ availability. Only significant differences are presented.

\begin{tabular}{|c|c|c|}
\hline & Acacia & Podocarpus \\
\hline \multicolumn{3}{|l|}{ 1) Low soil $N$ availability } \\
\hline Control & $\mathrm{NO}_{3}{ }^{-}, \mathrm{Gln}-\mathrm{N}>\mathrm{NH}_{4}{ }^{+}>\operatorname{Arg}-\mathrm{N}$ & $\begin{array}{l}\mathrm{Gln}-\mathrm{N}>\mathrm{NH}_{4}{ }^{+}, \mathrm{NO}_{3}{ }^{-}, \text {Arg-N } \\
\mathrm{NO}_{3}{ }^{-}>\text {Arg-N }\end{array}$ \\
\hline Competition with Pennisetum & $\mathrm{NO}_{3}{ }^{-}, \mathrm{Gln}-\mathrm{N}>\mathrm{NH}_{4}{ }^{+}$, Arg-N & $\mathrm{NO}_{3}{ }^{-}, \mathrm{Gln}-\mathrm{N}>\mathrm{NH}_{4}{ }^{+}$, Arg- $\mathrm{N}$ \\
\hline Competition with Cynodon & Gln-N $>\mathrm{NH}_{4}{ }^{+}$, Arg- $\mathrm{N}$ & Gln-N $>\mathrm{NO}_{3}{ }^{-}, \operatorname{Arg}-\mathrm{N}>\mathrm{NH}_{4}{ }^{+}$ \\
\hline \multicolumn{3}{|l|}{ 2) High soil $\mathrm{N}$ availability } \\
\hline Control & No differences & $\mathrm{NH}_{4}{ }^{+}>\mathrm{NO}_{3}{ }^{-}, \mathrm{Gln}-\mathrm{N}, \mathrm{Arg}-\mathrm{N}$ \\
\hline \multirow[t]{2}{*}{ Competition with Pennisetum } & $\begin{array}{l}\mathrm{NH}_{4}^{+}>\mathrm{NO}_{3}{ }^{-}, \mathrm{Gln}-\mathrm{N}, \text { Arg-N } \\
\text { Arg-N }>\mathrm{Gln}-\mathrm{N}\end{array}$ & $\begin{array}{l}\mathrm{NH}_{4}^{+}>\mathrm{NO}_{3}^{-}, \text {Gln-N, Arg-N } \\
\text { Gln-N }>\mathrm{NO}_{3}^{-}\end{array}$ \\
\hline & Pennisetum & Cynodon ${ }^{1}$ \\
\hline \multicolumn{3}{|l|}{ 1) Low soil $\mathrm{N}$ availability } \\
\hline Control & $\mathrm{NO}_{3}^{-}>\mathrm{NH}_{4}^{+}$, Gln-N, Arg-N & $\mathrm{NO}_{3}{ }^{-}, \mathrm{Gln}-\mathrm{N}>\mathrm{NH}_{4}{ }^{+}$ \\
\hline Competition with Acacia & $\begin{array}{l}\mathrm{NO}_{3}^{-}>\mathrm{NH}_{4}{ }^{+}, \mathrm{Gln}-\mathrm{N}, \text { Arg-N } \\
\mathrm{Gln}-\mathrm{N}>\text { Arg-N }\end{array}$ & $\mathrm{NO}_{3}^{-}>\mathrm{NH}_{4}^{+}$ \\
\hline Competition with Podocarpus & $\begin{array}{l}\mathrm{NO}_{3}^{-}>\mathrm{NH}_{4}^{+}, \text {Arg-N } \\
\mathrm{NH}_{4}^{+}, \mathrm{Gln}-\mathrm{N}>\text { Arg-N }\end{array}$ & $\begin{array}{l}\mathrm{NO}_{3}{ }^{-}>\mathrm{NH}_{4}{ }^{+}, \mathrm{Gln}-\mathrm{N}, \text { Arg-N } \\
\mathrm{Gln}-\mathrm{N}>\text { Arg-N }\end{array}$ \\
\hline \multicolumn{3}{|l|}{ 2) High soil $\mathrm{N}$ availability } \\
\hline Control & $\begin{array}{l}\mathrm{NH}_{4}{ }^{+}>\mathrm{NO}_{3}{ }^{-}, \mathrm{Gln}-\mathrm{N}, \text { Arg-N } \\
\text { Arg-N }>\mathrm{Gln}-\mathrm{N}\end{array}$ & \\
\hline Competition with Acacia & $\begin{array}{l}\mathrm{NH}_{4}^{+}>\operatorname{Arg}-\mathrm{N}>\mathrm{Gln}-\mathrm{N} \\
\mathrm{NO}_{3}^{-}>\mathrm{Gln}-\mathrm{N}\end{array}$ & \\
\hline Competition with Podocarpus & $\mathrm{NH}_{4}^{+}>$Arg- $\mathrm{N}>$ Gln-N & \\
\hline
\end{tabular}

${ }^{1}$ At low soil $N$ availability.

Native tree seedlings increase $N$ acquisition in competition with exotic grasses at high soil N availability

At high soil $\mathrm{N}$ availability, both tree species responded similarly to competition with the exotic grass Pennisetum by increasing $N$ acquisition. However, growth and biomass allocation were unaffected, which indicates that they might allocate the newly acquired $\mathrm{N}$ to storage rather than investing into growth, thereby reducing $\mathrm{N}$ availability for their competitors (Millard and Grelet 2010). These similarities between Acacia and Podocarpus in terms of net $\mathrm{N}$ uptake capacity and growth responses to competition with grasses indicate that both tree species use a common strategy, which is rather unexpected given the different successional status, growth strategies and physiological characteristics of the two tree species. Acacia is an early successional, fastgrowing and $\mathrm{N}_{2}$ fixing species, while Podocarpus is a slowgrowing, late-successional species (Smith et al. 2008). Thus, since fast-growing species would require higher amounts of $\mathrm{N}$ to meet their growth rate (Poorter et al. 2012), the observed 
increase in net $\mathrm{N}$ uptake capacity when growing in competition would be expected in Acacia and not in Podocarpus. However, previous studies have shown that Acacia seedlings are capable of $\mathrm{N}$-fixation (Sun et al. 1992), and that root nodulation in Acacia species is stimulated by competition with grasses (Cramer et al. 2007). Therefore the increased requirements of Acacia due to competition would probably be mitigated by its ability to fix atmospheric $\mathrm{N}_{2}$ (not quantified in our study) and thus reduce to an extent its dependency on external $\mathrm{N}$ supply. Moreover, the lack of response of Acacia to competition in terms of $\mathrm{N}$ uptake at low soil $\mathrm{N}$ availability in our study might also be attributed to a greater reliance on $\mathrm{N}_{2}$ fixation under limiting $\mathrm{N}$ conditions (Pfautsch et al. 2009).

Tree species differed in the acquired $\mathrm{N}$ forms: in competition fast-growing Acacia acquired more ammonium compared to single grown individuals, while slow-growing Podocarpus used glutamine- $\mathrm{N}$. This preference of inorganic vs organic $\mathrm{N}$ forms when competing might reflect different $\mathrm{N}$ acquisition strategies between fast- and slow-growers as reported for temperate tree seedlings (Simon et al. 2010, 2014, Li et al. 2015). The similar responses found here might be an early indication that, across biomes, $\mathrm{N}$ acquisition of trees is linked to growth strategy. These increases in net $\mathrm{N}$ uptake capacity as a response to competition were found only at high soil $\mathrm{N}$ availability suggesting mediation of $\mathrm{N}$ acquisition by soil $\mathrm{N}$ availability (e.g., Simon et al. 2013, Li et al. 2015). For Acacia, this could be related to a reduced nodule activity at high soil $\mathrm{N}$ concentrations, as it has been suggested that $\mathrm{N}$ acquisition from the soil, rather than $\mathrm{N}_{2}$ fixation, is energetically more efficient for this species when inorganic $N$ is readily available (Pfautsch et al. 2009). With regard to Podocarpus, an increase in organic $\mathrm{N}$ acquisition with competition was also reported for a temperate slow-growing tree species at high, but not low soil N (Li et al. 2015). Our results constitute a further example of increased $\mathrm{N}$ acquisition under competition with high $\mathrm{N}$ availability, but in a subtropical environment. Particularly in the view of increased atmospheric $\mathrm{N}$ deposition in the future (Rennenberg and Dannenmann 2015, Jia et al. 2016), the outcomes of competition in currently N-limited habitats are likely to change.

At low soil $\mathrm{N}$ availability, competition with grasses did not result in changes in $\mathrm{N}$ acquisition or biomass production and allocation for both tree species. Similarly, previous studies have reported a lack of effects of competition with the grass Cynodon dactylon on the growth (i.e., biomass, basal diameter and stem height) of a different Acacia species (A. smallii Isely) on nonsupplemented native soil (Cohn et al. 1989). Nevertheless, this grass species hinders the growth of native tree seedlings in the field and is reported as a threat to restoration efforts in subtropical Australia (M. Amos, personal communication). Since we did not observe these negative effects in our study, it is likely that the impacts of the competition with Cynodon on tree seedling growth are evident at later developmental stages of both the grass and the tree species than the ones considered here. The lack of response to competition of the tree seedlings regarding total biomass could also be due to the short duration of our experiment, considering the relatively slow growth of tree seedlings compared to grasses. Previous studies reporting negative effects of grasses on Acacia measured responses over longer periods, e.g., 3 years (Messina and Barton 1985), and 8 years (Florentine and Westbrooke 2004). Furthermore, the effect of the grass on tree seedlings may be mediated by soil $\mathrm{N}$ availability: in our study, the effects of competition with Cynodon were not investigated at high soil $N$ availability, but it has been reported that competition with Cynodon combined with an increase in soil nutrient availability results in $70-90 \%$ reduction in growth of $A$. smallii (Cohn et al. 1989).

\section{Exotic grasses respond to competition for $N$ depending on the competitor and soil $N$ availability}

For the exotic grasses, four strategies were identified which depended on the competing species and soil $\mathrm{N}$ availability: (1) Pennisetum biomass was reduced in competition with both tree species compared to the control at high, but not low soil $\mathrm{N}$ availability suggesting that the outcome of competitive interactions between native tree seedlings and Pennisetum depends on soil $\mathrm{N}$ availability. Moreover, the biomass of Pennisetum at high soil $\mathrm{N}$ availability, even if reduced by competition with the tree seedlings, was still higher than its biomass at low soil $N$ in the absence of interspecific competition, suggesting that, at least in the short-term, the grass is more successful than the tree seedlings at high soil $\mathrm{N}$ availability, despite the observed negative effects of competition. (2) The grass Cynodon showed a similar strategy as Pennisetum, i.e., a reduction in biomass but no change in $\mathrm{N}$ acquisition, but only when competing with Acacia, but not Podocarpus, indicating that for both grass species the response to competition depends on the competitor. (3) Resource allocation shifted to aboveground at the expense of belowground tissue production (Aerts et al. 1991) for Pennisetum competing with Podocarpus at low and high soil N. This suggests that, despite the fact that shading from the tree seedlings was not apparent, the potential competition for light is more relevant for Pennisetum than competition for belowground resources (Poorter et al. 2012), thus not leading to an increase in $\mathrm{N}$ acquisition. However, these results were not observed when grown in competition with Acacia or for the grass Cynodon indicating that this biomass allocation strategy of Pennisetum also depends on the competing species, but not soil $\mathrm{N}$ availability. (4) Competition with Podocarpus, but not Acacia, resulted in increased net nitrate uptake in Cynodon, but not Pennisetum suggesting different $\mathrm{N}$ acquisition strategies between the two exotic grass species that vary with the competing tree species. Overall, our results suggest that the outcome of competitive interactions between native tree seedlings and exotic grasses are species-specific and mediated by soil $\mathrm{N}$ availability. 
Differences in $N$ acquisition strategies between species suggest potential for niche differentiation

All four species took up both inorganic and organic $\mathrm{N}$ forms, although specifics varied according to $\mathrm{N}$ forms. Nitrate acquisition was higher in Pennisetum and Acacia compared to Podocarpus, consistent with their successional status and the low abundance of nitrate in late-successional forest soils as well as a reduced nitrate use capacity in late-successional tree species (Kronzucker et al. 1997, Britto and Kronzucker 2013). At sites with higher soil nitrate availability, e.g., disturbed areas, the grass Pennisetum would have a competitive advantage over Podocarpus, but not Acacia, highlighting the importance of species-specific consideration for reforestation programs. Moreover, glutamine-N acquisition was higher for Acacia than Podocarpus, contrary to what we expected according to their successional status, since soil amino acid content generally increases as succession progresses (Werdin-Pfisterer et al. 2009). Nevertheless, glutamine-N acquisition was higher in both tree species compared to Pennisetum indicating a potential for avoidance of competition via the use of the different $N$ forms (Simon et al. 2017). Overall, that plants take up organic $\mathrm{N}$ forms is now well established and has been reported for numerous plant species and ecosystems (Näsholm et al. 2009). Moreover, its ecological relevance is increasingly recognized due to the resulting niche differentiation and consequences in terms of species coexistence (Näsholm et al. 2009, Simon et al. 2014, Li et al. 2015, Andersen et al. 2017, Uscola et al. 2017).

Comparing within tree and grass species, higher soil $\mathrm{N}$ availability resulted in increased inorganic and organic $\mathrm{N}$ acquisition in general, which for Pennisetum was combined with increased biomass production (for Cynodon data is only available for low soil N). This increase in grass biomass production with increasing soil $\mathrm{N}$ availability while there was no short-term response of the tree seedlings suggests a potential advantage for the grass in habitats on $\mathrm{N}$-rich soils or in future scenarios with increased atmospheric $\mathrm{N}$ deposition compared to the native trees. This link between high resource availability and success of invasive species has been explored in previous studies (e.g., Badgery et al. 2005, Gao et al. 2014, Yelenik et al. 2017), and has been linked to invader traits related to exploitation and efficient use of resources, which allows for better growth (Huangfu et al. 2016, Yelenik et al. 2017). In our study, although competition with seedlings of both tree species reduced the total biomass of Pennisetum compared to Pennisetum grown in controls, the increase in Pennisetum biomass in response to higher soil $\mathrm{N}$ availability was of greater magnitude. Increases in the productivity of Pennisetum with $\mathrm{N}$ fertilization resulting in its dominance at fertilized sites have been reported before (Mears 1970, Barton et al. 2008), and under such conditions, Pennisetum might be more competitive than tree seedlings. Moreover, the potential of Acacia to induce increases in soil $\mathrm{N}$ availability over time as a consequence of its $\mathrm{N}_{2}$ fixing ability has been shown before in silvopastoral systems (Power et al. 2003). Thus, increased N supply as a consequence of the use of $\mathrm{N}_{2}$ fixing tree species such as Acacia might favour the growth and potential dominance of Pennisetum at restoration sites.

\section{Methodological considerations}

Our experimental approach has several limitations. First, the competitor grasses were grown from seeds, whereas the trees were purchased as seedlings. This set up was selected because our aim was to mimic the actual timing in a restoration setting under field conditions for which tree species are planted as seedlings for reforestation and grasses arrive at a later time. Thus, a comparison between trees and grasses cannot exclude differences due to variation in developmental stages between tree species and grasses. Specifically, the lack of response in seedling biomass reported here might not persist with older or larger grasses. Second, tree seedlings differed in their age at the start of the experiment which might have influenced their responses to competition and/or soil $\mathrm{N}$ availability in our experiment. However, given the differences in growth rates between the tree species used in this study, seedlings of similar age would have likely differed in their initial above- and belowground dimensions, thereby introducing another variable. Third, the experiment ran for 8 weeks which might not be sufficient time for a response in tree seedling biomass, however they did respond with regard to $\mathrm{N}$ acquisition from the soil. Finally, the artificial $\mathrm{N}$ solution used in this study is based on a low and high $\mathrm{N}$ forest site (Dannenmann et al. 2009, Stoelken et al. 2010, respectively) as well as the occurrence of glutamine and arginine in soils of subtropical Queensland (Holst et al. 2012), but not actual measured concentrations at subtropical restoration sites.

\section{Conclusions}

In our study, native tree seedlings and exotic grasses responded to competition with two distinct response types: (1) a reduction in biomass, but no change in $\mathrm{N}$ acquisition, (2) an increase in $\mathrm{N}$ acquisition without a change in biomass. This outcome depended on the competing species and soil $\mathrm{N}$ availability. Thus, we suggest that these aspects be considered also for ecosystem restoration and management, with special attention to the potential feedbacks between native trees possessing traits such as $\mathrm{N}_{2}$ fixing ability and exotic grasses that may benefit from the resulting increase in soil $\mathrm{N}$ availability. Exotic grasses such as Pennisetum and Cynodon are considered a high priority for control in Australia and their suppression can promote the reestablishment of woody vegetation, thus determining the success of subtropical rainforest restoration programs (Florentine and Westbrooke 2004, Downey et al. 2010, Shoo and Catterall 2013). We found no common N acquisition strategy across species in response to competition between native trees and invasive grasses indicating the need to consider species-specific approaches in restoration management plans. 


\section{Acknowledgments}

The authors are grateful to Nicole Robinson, Stéphane Guillou and Mónica Salazar (The University of Queensland, Brisbane, Australia) for their assistance with ${ }^{15} \mathrm{~N}$ uptake experiments, and Lisa Xian (The University of Queensland, Brisbane, Australia) and Silvia Kuhn (University of Konstanz, Konstanz, Germany) for assistance during sample processing. We thank Mark Amos (Lake Baroon Catchment Care Group, Maleny, Australia) for his help in species selection, and Mark van Kleunen (University of Konstanz, Konstanz, Germany) for comments on an early version of the manuscript.

\section{Conflict of interest}

None declared.

\section{Funding}

Funding was provided to Judy Simon by the Young Scholar Fund (No. P83960614 FP 606/14) of the University of Konstanz.

\section{References}

Aerts R, Boot RGA, van der Aart PJM (1991) The relation between above- and belowground biomass allocation patterns and competitive ability. Oecologia 87:551-559.

Agren G, Wetterstedt J, Billberger M (2012) Nutrient limitation on terrestrial plant growth - modeling the interaction between nitrogen and phosphorus. New Phytol 194:953-960.

Andersen K, Mayor J, Turner B (2017) Plasticity in nitrogen uptake among plant species with contrasting nutrient acquisition strategies in a tropical forest. Ecology 98:1388-1398.

Anderson M, Gorley R, Clarke K (2008) PERMANOVA+ for PRIMER: Guide to Software and Statistical Methods. PRIMER-E, Plymouth, UK.

Ashton IW, Miller AE, Bowman WD, Suding KN (2010) Niche complementarity due to plasticity in resource use: plant partitioning of chemical N forms. Ecology 91:3252-3260.

Badgery WB, Kemp DR, Michalk DL, King WM (2005) Competition for nitrogen between Australian native grasses and the introduced weed Nassella trichotoma. Ann Bot-London 96:799-809.

Barbosa ER, van Langevelde F, Tomlinson KW, Carvalheiro LG, Kirkman K, de Bie S, Prins HH (2014) Tree species from different functional groups respond differently to environmental changes during establishment. Oecologia 174:1345-1357.

Barton L, Wan GGY, Buck RP, Colmer TD (2008) Nitrogen increases evapotranspiration and growth of a warm-season turfgrass. Agron J 101:17-24.

BassiriRad H (2000) Kinetics of nutrient uptake by roots: responses to global change. New Phytol 147:155-169.

Birnbaum C, Barrett L, Thrall P, Leishmann M (2012) Mutualisms are not constraining cross-continental invasion success of Acacia species within Australia. Divers Distrib 18:962-976.
Bloor JM, Leadley PW, Barthes L (2008a) Responses of Fraxinus excelsior seedlings to grass-induced above- and below-ground competition. Plant Ecol 194:293-304.

Bloor JM, Barthes L, Leadley PW (2008b) Effects of elevated $\mathrm{CO}_{2}$ and N on tree-grass interactions: an experimental test using Fraxinus excelsior and Dactylis glomerata. Funct Ecol 22:537-546.

Bradley BA, Blumenthal DM, Wilcove DS, Ziska LH (2010) Predicting plant invasions in an era of global change. Trends Ecol Evol 25: 310-318.

Britto DT, Kronzucker HJ (2013) Ecological significance and complexity of N-source preference in plants. Ann Bot-London 112:957-963.

Brooker R (2006) Plant-plant interactions and environmental change. New Phytol 171:271-284.

Brooker R, Maestre F, Callaway R et al. (2008) Facilitation in plant communities: the past, the present, and the future. J Ecol 96:18-34.

Callaway R, Walker L (1997) Competition and facilitation: a synthetic approach to interactions in plant communities. Ecology 78: 1958-1965.

Casper B, Jackson R (1997) Plant competition underground. Annu Rev Ecol Syst 28:545-570.

Catteral CP, Harrison DA (2006) Rainforest restoration activities in Australia's tropics and subtropics. Cooperative Research Centre for Tropical Rainforest Ecology and Management, Cairns, Australia.

Cohn E, Van Auken O, Bush J (1989) Competitive interactions between Cynodon dactylon and Acacia smallii seedlings at different nutrient levels. Am Midl Nat 121:265-272.

Coll L, Balandier P, Picon-Cochard C (2004) Morphological and physiological responses of beech (Fagus sylvatica) seedlings to grassinduced belowground competition. Tree Physiol 24:45-54.

Cramer MD, Chimphango SB, van Cauter A, Waldram MS, Bond WJ (2007) Grass competition induces $N_{2}$ fixation in some species of African Acacia. J Ecol 95:1123-1133.

Cramer MD, van Cauter A, Bond WJ (2010) Growth of $\mathrm{N}_{2}$-fixing African savanna Acacia species is constrained by below-ground competition with grass. J Ecol 98:156-167.

Cramer MD, Wakeling JL, Bond WJ (2012) Belowground competitive suppression of seedling growth by grass in an African savanna. Plant Ecol 213:1655-1666.

D'Antonio CM, Vitousek PM (1992) Biological invasions by exotic grasses, the grass/fire cycle, and global change. Annu Rev Ecol Syst 23:63-87.

Dannenmann M, Simon J, Gasche R et al. (2009) Tree girdling provides insight on the role of labile carbon in nitrogen partitioning between soil microorganisms and adult European beech. Soil Biol Biochem 41: 1622-1631.

Davis MA, Wrage K, Reich PB (1998) Competition between tree seedlings and herbaceous vegetation: support for a theory of resource supply and demand. J Ecol 86:652-661.

Davis MA, Wrage KJ, Reich PB, Tjoelker MG, Schaeffer T, Muermann C (1999) Survival, growth, and photosynthesis of tree seedlings competing with herbaceous vegetation along a water-light-nitrogen gradient. Plant Ecol 145:341-350.

Doran JC, Turnbull JW (eds) (1997) Australian trees and shrubs: species for land rehabilitation and farm planting in the tropics. Australian Centre for International Agricultural Research, Canberra, Australia.

Doust SJ, Erskine PD, Lamb D (2008) Restoring rainforest species by direct seeding: tree seedling establishment and growth performance on degraded land in the wet tropics of Australia. Forest Ecol Manag 256:1178-1188.

Downey PO, Scanlon TJ, Hosking JR (2010) Prioritizing weed species based on their threat and ability to impact on biodiversity: a case study from New South Wales. Plant Prot Q 25:111-126.

Elgar AT, Freebody K, Pohlman CL, Shoo LP, Catterall CP (2014) Overcoming barriers to seedling regeneration during forest restoration 
on tropical pasture land and the potential value of woody weeds. Front Plant Sci 5:200.

Eller CB, Oliveira RS (2017) Effects of nitrogen availability on the competitive interactions between an invasive and a native grass from Brazilian cerrado. Plant Soil 410:63-72.

Epron D, Koutika LS, Tchichelle SV, Bouillet JP, Mareschal L (2006) Uptake of soil mineral nitrogen by Acacia mangium and Eucalyptus urophylla $\times$ grandis: no difference in N form preference. J Plant Nutr Soil Sc 179:726-732

Erskine P, Lamb D, Bristow M (eds) (2005) Reforestation in the tropics and subtropics of Australia using rainforest tree species. Rural Industries Research and Development Corporation, Canberra, Australia.

Florentine SK, Westbrooke ME (2004) Evaluation of alternative approaches to rainforest restoration on abandoned pasturelands in tropical North Queensland, Australia. Land Degrad Dev 15:1-13.

Fraterrigo JM, Strickland MS, Keiser AD, Bradford MA (2011) Nitrogen uptake and preference in a forest understory following invasion by an exotic grass. Oecologia 167:781-791.

Gageler R, Bonner M, Kirchhof G, Amos M, Robinson N, Schmidt S, Shoo LP (2014) Early response of soil properties and function to riparian rainforest restoration. PLoS One 9:e104198.

Gao Y, Yu HW, He WM (2014) Soil space and nutrients differentially promote the growth and competitive advantages of two invasive plants. J Plant Ecol 7:396-402.

Gessler A, Schneider S, von Sengbusch D, Weber P, Hanemann U, Huber C, Rothe A, Kreutzer K, Rennenberg H (1998) Field and laboratory experiments on net uptake of nitrate and ammonium by the roots of spruce (Picea abies) and beech (Fagus sylvatica) trees. New Phytol 138:275-285.

Gessler A, Kreuzwieser J, Dopatka T, Rennenberg H (2002) Diurnal courses of ammonium net uptake by the roots of adult beech (Fagus sylvatica) and spruce (Picea abies) trees. Plant Soil 240:23-32.

Gioria M, Osborne BA (2014) Resource competition in plant invasions: emerging patterns and research needs. Front Plant Sci 5:501.

Hodge A (2004) The plastic plant: root responses to heterogeneous supplies of nutrients. New Phytol 162:9-24.

Holst J, Brackin R, Robinson N, Lakshmanan P, Schmidt S (2012) Soluble inorganic and organic nitrogen in two Australian soils under sugarcane cultivation. Agric Ecosyst Environ 155:16-26.

Huangfu C, Li H, Chen X, Liu H, Wang H, Yang D (2016) Response of an invasive plant, Flaveria bidentis, to nitrogen addition: a test of formpreference uptake. Biol Invasions 18:3365-3380.

Jeltsch F, Weber GE, Grimm V (2000) Ecological buffering mechanisms in savannas: a unifying theory of long-term tree-grass coexistence. Plant Ecol 161:161-171.

Jia Y, Yu G, Gao Y, He N, Wang Q, Jiao C, Zuo Y (2016) Global inorganic nitrogen dry deposition inferred from ground- and space-based measurements. Sci Rep 6:19810.

Judd BI (1979) Handbook of tropical forage grasses. Garland, New York.

Kanowski J, Catterall CP, Wardell-Johnson GW, Proctor H, Reis T (2003) Development of forest structure on cleared rainforest land in eastern Australia under different styles of reforestation. Forest Ecol Manag 183:265-280.

Kielland K, McFarland J, Olson K (2006) Amino acid uptake in deciduous and coniferous taiga ecosystems. Plant Soil 288:291-307.

Kronzucker HJ, Siddiqi Y, Glass ADM (1997) Conifer root discrimination against soil nitrate and the ecology of forest succession. Nature 385 : 59-61.

Kuster TM, Wilkinson A, Hill PW, Jones DL, Bardgett RD (2016) Warming alters competition for organic and inorganic nitrogen between coexisting grassland plant species. Plant Soil 406:117-129.
Li X, Rennenberg H, Simon J (2015) Competition for nitrogen between Fagus sylvatica and Acer pseudoplatanus seedlings depends on soil nitrogen availability. Front Plant Sci 6:302

Loik ME, Holl KD (2001) Photosynthetic responses of tree seedlings in grass and under shrubs in early-successional tropical old fields, Costa Rica. Oecologia 127:40-50.

Ludwig F, de Kroon H, Prins HHT, Berendse F (2001) Effects of nutrients and shade on tree-grass interactions in an East African savanna. J Veg Sci 12:579-588.

Marschner $H$ (1995) Mineral nutrition of higher plants. London Academic Press, London, UK.

McKane R, Johnson L, Shaver G et al. (2002) Resource-based niches provide a basis for plant species diversity and dominance in arctic tundra. Nature 412:68-71.

Mears PT (1970) Kikuyu (Pennisetum clandestinum) as a pasture grass a review. Trop Grasslands 4:139-152.

Meli P, Dirzo R (2013) Effects of grasses on sapling establishment and the role of transplanted saplings on the light environment of pastures: implications for tropical forest restoration. Appl Veg Sci 16:296-304.

Messina MG, Barton IL (1985) Early growth and survival of Acacia melanoxylon: effect of weed control and fertiliser. New Zeal J For Sci 15: 111-116.

Millard P, Grelet GA (2010) Nitrogen storage and remobilization by trees: ecophysiological relevance in a changing world. Tree Physiol 30:1083-1095.

Miller AE, Bowman WD, Suding KN (2007) Plant uptake of inorganic and organic nitrogen: neighbor identity matters. Ecology 88:1832-1840.

Moustakas A, Kunin WE, Cameron TC, Sankaran M (2013) Facilitation or competition? Tree effects on grass biomass across a precipitation gradient. PLoS One 8:e57025.

Näsholm T, Kielland K, Ganeteg U (2009) Uptake of organic nitrogen by plants. New Phytol 182:31-48.

Persson J, Högberg P, Ekblad A, Högberg MN, Nordgren A, Näsholm T (2003) Nitrogen acquisition from inorganic and organic sources by boreal forest plants in the field. Oecologia 137:252-257.

Pfautsch S, Rennenberg H, Bell TL, Adams MA (2009) Nitrogen uptake by Eucalyptus regnans and Acacia spp. - preferences, resource overlap and energetic costs. Tree Physiol 29:389-399.

Poorter H, Niklas KJ, Reich PB, Oleksyn J, Poot P, Mommer L (2012) Biomass allocation to leaves, stems and roots: meta-analyses of interspecific variation and environmental control. New Phytol 193:30-50.

Power IL, Thorrold BS, Balks MR (2003) Soil properties and nitrogen availability in silvopastoral plantings of Acacia melanoxylon in North Island, New Zealand. Agroforest Syst 57:225-237.

Quinteros CP, Bava JO, López Bernal PM, Gobbi ME, Defossé GE (2017) Competition effects of grazing-modified herbaceous vegetation on growth, survival and water relations of lenga (Nothofagus pumilio) seedlings in a temperate forest of Patagonia, Argentina. Agroforest Syst 91:597-611.

Rennenberg H, Dannenmann M (2015) Nitrogen nutrition of trees in temperate forests - the significance of nitrogen availability in the pedosphere and atmosphere. Forests 6:2820-2835.

Rennenberg H, Dannenmann M, Gessler A, Kreuzwieser J, Simon J, Papen H (2009) Nitrogen balance in forest soils: nutritional limitation of plants under climate change stresses. Plant Biol 11:4-23.

Rossiter-Rachor NA, Setterfield SA, Douglas MM, Hutley LB, Cook GD, Schmidt S (2009) Invasive Andropogon gayanus (gamba grass) is an ecosystem transformer of nitrogen relations in Australian savanna. Ecol Appl 19:1546-1560.

Sankaran M, Ratnam J, Hanan NP (2004) Tree-grass coexistence in savannas revisited - insights from an examination of assumptions and mechanisms invoked in existing models. Ecol Lett 7:480-490. 
Schmidt S, Stewart GR (1999) Glycine metabolism by plant roots and its occurrence in Australian plant communities. Aust J Plant Physiol 26: 253-264.

Shoo LP, Catterall CP (2013) Stimulating natural regeneration of tropical forest on degraded land: approaches, outcomes, and information gaps. Restor Ecol 21:670-677.

Simon J, Waldhecker P, Brüggemann N, Rennenberg H (2010) Competition for nitrogen sources between European beech (Fagus sylvatica) and sycamore maple (Acer pseudoplatanus) seedlings. Plant Biol 12:453-458.

Simon J, Dannenmann M, Gasche R, Holst J, Mayer H, Papen H, Rennenberg H (2011) Competition for nitrogen between adult European beech and its offspring is reduced by avoidance strategy. Forest Ecol Manag 262:105-114.

Simon J, Dong F, Buegger F, Rennenberg H (2013) Rhizospheric NO affects $\mathrm{N}$ uptake and metabolism in Scots pine (Pinus sylvestris L.) seedlings depending on soil $\mathrm{N}$ availability and $\mathrm{N}$ source. Plant Cell Environ 36:1019-1026.

Simon J, Li X, Rennenberg H (2014) Competition for nitrogen between European beech and sycamore maple shifts in favour of beech with decreasing light availability. Tree Physiol 34:49-60.

Simon J, Dannenmann M, Pena R, Gessler A, Rennenberg H (2017) Nitrogen nutrition of beech forests in a changing climate: importance of plant-soil-microbe water, carbon, and nitrogen interactions. Plant Soil 418:89-114.

Smith NJC, Zahid DM, Ashwath N, Midmore DJ (2008) Seed ecology and successional status of 27 tropical rainforest cabinet timber species from Queensland. Forest Ecol Manag 256:1031-1038.

Soliveres S, Maestre F (2014) Plant-plant interactions, environmental gradients and plant diversity: a global synthesis of community-level studies. Perspect Plant Ecol 16:154-163.
Stoelken G, Simon J, Ehlting B, Rennenberg H (2010) The presence of amino acids affects inorganic $\mathrm{N}$ uptake in non-mycorrhizal seedlings of European beech (Fagus sylvatica). Tree Physiol 30:1118-1128.

Sun JS, Sands R, Simpson RJ (1992) Genotypic variation in growth and nodulation by seedlings of Acacia species. Forest Ecol Manag 55: 209-223.

Trinder C, Brooker R, Robinson D (2013) Plant ecology's guilty little secret: understanding the dynamics of plant competition. Funct Ecol 27:918-929.

Tylianakis JM, Didham RK, Bascompte J, Wardle DA (2008) Global change and species interactions in terrestrial ecosystems. Ecol Lett 11:1351-1363.

Uscola M, Villar-Salvador P, Oliet J, Warren CR (2017) Root uptake of inorganic and organic $\mathrm{N}$ chemical forms in two coexisting Mediterranean forest trees. Plant Soil 415:387-392.

van der Waal C, de Kroon H, de Boer WF et al. (2009) Water and nutrients alter herbaceous competitive effects on tree seedlings in a semiarid savanna. J Ecol 97:430-439.

Verlinden M, De Boeck HJ, Nijs I (2014) Climate warming alters competition between two highly invasive alien plant species and dominant native competitors. Weed Res 54:234-244.

Weigelt A, Bol R, Bardgett RD (2005) Preferential uptake of soil nitrogen forms by grassland plant species. Oecologia 142:627-635.

Werdin-Pfisterer NR, Kielland K, Boone RD (2009) Soil amino acid composition across a boreal forest succesional sequence. Soil Biol Biochem 41:1210-1220.

Wilson SD, Tilman D (1991) Component of plant competition along an experimental gradient of nitrogen availability. Ecology 72: 1050-1065.

Yelenik SG, D'Antonio CM, August-Schmidt E (2017) The influence of soil resources and plant traits on invasion and restoration in a subtropical woodland. Plant Ecol 218:1149-1161. 